\title{
Effect of Using Drone Brood Cells as Traps Against Varroa destructor (Varroa Mite)
}

\author{
Mustafa Güneşdoğdu ${ }^{1, a, *}$, Ahmet Şekeroğluª,b, Brian Tainika ${ }^{2, c}$ \\ ${ }^{1}$ Department of Animal Science and Technologies, Faculty of Applied Sciences, Muş Alparslan University, 49250 Muş, Turkey. \\ ${ }^{2}$ Department of Animal Production and Technologies, Faculty of Agricultural Sciences and Technologies, Niğde Ömer Halisdemir \\ University, 51240 Niğde, Turkey.
}

*Corresponding author

A R T I C L E I N F O A B S T R A C T

Research Article

Today, the honeybee parasite Varroa destructor is thought to be the most dangerous creature in the beekeeping industry worldwide. In this study, the efficacy of using drone brood cells (known to have no residue concerns in bee products and harmless on bee health) as traps against $V$. destructor was investigated. A total of 16 honeybee (Apis mellifera) colonies with $V$. destructor infestation

Received : 16/04/2021

Accepted : 19/05/2021 percentage of less than $5 \%$ were used for the trial. The treatment group consisted of 8 colonies that were randomly assigned to molded drone comb (comb with $5.4 \mathrm{~mm}$ hexagonal cells). The other 8 were assigned to unmolded comb to form the control group. In the trial groups, after 20 days (from 10th May), all drone combs with complete pupation were removed and destroyed on 30th May, 20th June, 10th July, 30th July, and 20th August. During the trial, varroa mite infestation rate (mean abundance), colony development, and varroa mite preference for drone and work bee brood cells were determined. The results showed that the application of drone brood cells as a control method was statistically significant against $V$. destructor, and did not negatively affect colony development. On the other hand, V.destructor's preference for both drone and worker bee brood cells among the groups was not statistically significant. In conclusion, drone brood cells ensured an approximately $43 \%$ success rate as traps against $V$. destructor compared to the control group. The effective application of drone brood cells as traps in combination with other Varroa mite control methods should be investigated.

Apis mellifera

Beekeeping

Brood cell

Drone bee

Honeybee https://orcid.org/0000-0002-1896-2449

\section{Introduction}

Beekeeping is a common agricultural activity for pollination and the production of bee products. Honeybees contribute directly to humanity with their products such as honey, pollen, propolis, royal jelly, wax, and bee venom, and indirectly with pollination in plants. Furthermore, plant origin foods account for about $35 \%$ of the world's food production. $85 \%$ of these plants are pollinated by insects, and the share of the honeybees, Apis mellifera as pollinating insects is about $80 \%$ (Klein et al., 2007; Potts et al., 2010; Smart et al., 2018). In terms of sustainable agricultural production and food security, the health protection of the honeybee is very important. Honeybee colonies have been decreasing numerically in the last 50 years in the world due to proportional reductions in honeybee health (Liu et al., 2016; Smart et al., 2018). This is due to factors such as harvesting methods, parasites, growing and feeding systems, climate changes due to global warming, and genotype (Goulson et al., 2015; Liu et al., 2016; Smart et al., 2018). The parasite of the most economic importance in honeybee keeping is the Varroa mite (Varroa destructor) (Goulson et al., 2015; Liu et al., 2016; Smart et al., 2018). The methods (e.g., chemical, physical, and biological) of combating this parasite have been studied for years, but no definitive solutions have been found to destroy it completely (Szczurek et al., 2019). Despite the long-term use of the chemical method, positive results have not been completely achieved due to the mite resistance to chemicals (Goodwin et al., 2005). Also, the above method leads to a decrease in the quality of bee products due to chemical residues in bee products and deterioration in bee health (Berry et al., 2013; Mancuso et al., 2020). The limitations of chemical control accelerated the development and application of physical and biological parasite control methods although they have been unable to provide a precise solution (Guichard et al., 2020). 
The varroa mites remain a global challenge and if not fought in a timely and adequate way, their negative effects include a decrease in the quality of bee and bee products and destruction of colonies which decreases the production of bee products. The parasite has a high preference for brood in the drone bee cells (Fuchs, 1990; Al Toufailia et al., 2018). After about 7 days of life on adult bees, the parasites enter the brood cells which are about to cap for their breeding and multiplication (Anderson and Trueman, 2000). The varroa mites enter the drone and worker bee brood cells, 40 and 20 hours respectively before they cap (Rosenkraz et al., 2010). It is established that the parasite preference for drone bee cells is a result of the longer pupa stage that enhances their progenitive potential compared with worker and queen bee cells (Rosenkraz et al., 2010; Traynor et al., 2020). In addition, 1 and 2-3 adult daughter mites are produced by the varroa mite from the worker and drone brood cells, respectively. These emerge out of the brood cells with the mother mite and the hatching bee. Those that have not become adult mites die after the brood is out of sight (Rosenkraz et al., 2010; Traynor et al., 2020). The female Varroa destructor enters the brood cell about 5 hours before the brood honeycomb cells are capped and begin to absorb brood blood (hemolymph) and fat body tissue (Rosenkraz et al., 2010; Ramsey et al., 2019). A few hours after the female Varroa destructor enters the cell, oogenesis begins, followed by vitellogenesis, and about 70 hours later, the female $V$. destructor lays her first egg (Ifantidis, 1983; Rosenkraz et al., 2010). These first eggs are normally haploid males. Within 30 hours, these males become adults and mate with females, leaving diploid (2n) eggs (Rehm and Ritter, 1989; Martin, 1994). In spite of the application of various control methods in bee production, varroa mite is persistently one of the major causes of colony losses in several countries. Therefore, in this study, the effect of using the biologically "drone brood cells method" as traps against the Varroa destructor parasite was investigated.

\section{Material and Method}

The trial was conducted at the apiary of Niğde Ömer Halisdemir University Ayhan Şahenk Agricultural Application and Research center, Niğde province, Turkey. The province is located in the Central Anatolia region of Turkey at an altitude of $1299 \mathrm{~m}\left(37^{\circ} 58^{\prime} 00^{\prime \prime} \mathrm{N} 34^{\circ} 40^{\prime} 45^{\prime \prime} \mathrm{E}\right)$. The trial took place from 10th May to 20th August 2019.

\section{Bee and Hive Material}

The trial used bee and hive material belonging to a commercial business. A total of 16 honeybee colonies that were partially balanced in terms of adult bees and brood were used. Their queen bees were of the same age (bred in 2018) and breed hybrid (F1) (Apis mellifera caucasica $\mathrm{x}$ Apis mellifera anatoliaca). The structure of the colonies was the Langstroth model with a capacity of 10 wooden frames. The colonies with Varroa destructor percentage infestation of less than $5 \%$ were selected for the study. From the 16 colonies, those whose Varroa destructor infestation rate was close to each other were selected and randomly divided into two groups of 8 (treatment and control). The colonies in the treatment group received one drone frame (For the aim of Varroa destructor control and trapping in honeybee colonies, combs with cells sized for drones $(5.4 \mathrm{~mm}$ hexagonal cells) were used). The control group colonies were not altered during the trial period. The queen bee was caged on the drone frame for 24 hours and then released each time the comb was taken from the colony. Drone combs that had completely undergone pupation after 20 days (from 10th May) were removed from the colony, and the above procedure was repeated 5 times (on 30th May, 20th June, 10th July, 30th July, and 20th August 2019).

\section{Determination of Pre- and Post-Trial Infestation Percentage of Varroa Destructor in The Colonies}

This was determined using the icing sugar method described by Panziera et al. (2017). Briefly, about 200-250 adult bees from any frame with capped larvae cells in the colony were collected and placed in a jar with a mesh lid in the middle. $50 \mathrm{~g}$ of icing sugar was added to the jar via the mesh. The jar was shaken for 3 minutes to ensure that all the bees were covered with icing sugar and then inverted. The detached varroa that fell via the mesh lid were collected in a sieve to remove the icing sugar. The mites were tipped onto the clean piece of paper and counted. The number of bees and the counted Varroa mites were used to calculate the $V$. destructor percent infestation of each colony with the formula below (Çetin, 2010).

$$
\operatorname{VIAB}(\%)=(\mathrm{TVIAB} / \mathrm{TNAB}) \times 100
$$

VIAB :Varroa destructor percent infestation on adult bees

TVIAB :Total number of Varroa destructor on adult bees

TNAB :Total number of adult bees

\section{Determination of Infestation Percentage of Varroa Destructor in Drone and Worker Bee Pupae}

To determine Varroa destructor's percent infestation in drone and worker bee cells, 200 pupae in one worker and drone comb were removed from the cells with the help of tweezers. This was done each time the combs were removed from every colony on 30th May, 20th June, 10th July, 30th July, and 20th August. While uncapping the cells, the pupae with $V$. destructor were counted. In the control group colonies, 200 worker bee pupae were removed from the worker comb and counted. 200 of the drone pupae in the corner parts of the other combs were uncapped and counted. Varroa destructor percentage in brood cells was calculated using the expression below (Çetin, 2010).

$$
\mathrm{VICC}=(\mathrm{TV} / \mathrm{TNUC}) \times 100
$$

VICC :Varroa destructor infestation in the cells that were capped,

TV :Total Varroa destructor in the cells that were uncapped by the researcher

TNUC :Total number of cells that were uncapped looking for mites.

The obtained Varroa destructor infestation rate (percentage) lead to the determination of varroa mite preference for drone brood. This was calculated using the formula below (Fushs, 1990).

Drone cell preference $=($ Varroa infestation percentage in drone cells/ Varroa infestation percentage worker cells) 

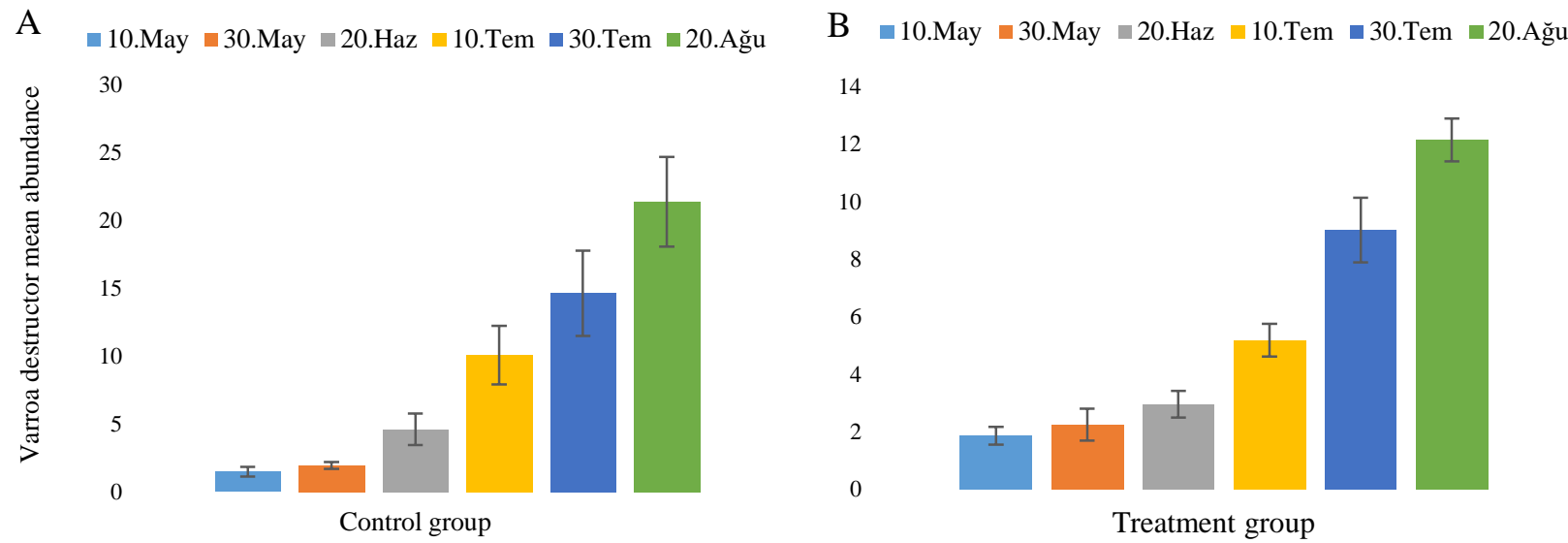

Figure 1(A) and (1B). Varroa destructor mean abundance in the treatment and control groups over time, respectively

Table 1. Average Varroa destructor mean abundance before (10th May 2019) and after (20th August 2019) the study (\%) via sugar shakes (Mean \pm SEM)

\begin{tabular}{l|ccc}
\hline \multicolumn{1}{c|}{ Group } & Number & Before trial & After trial \\
\hline Treatment & 8 & $1.87 \pm 0.31$ & $12.14 \pm 0.75^{\mathrm{b}}$ \\
Control & 8 & $1.49 \pm 0.35$ & $21.37 \pm 3.3^{\mathrm{a}}$ \\
$\mathrm{P}$ & & 0.461 & 0.036 \\
\hline
\end{tabular}

SEM, standard error of the mean, ${ }^{a, b}$ Values within a column with different superscripts differ significantly at $\mathrm{P}<0.05$

Table 2. Varroa destructor percent infestation of drone and work pupae over time (Mean \pm SEM)

\begin{tabular}{c|ccccccc}
\hline Variable & Group & $\mathrm{n}$ & May 30 & June 20 & July 10 & July 30 & Aug 20 \\
\hline \multirow{2}{*}{ Drone PI } & Control & 8 & $4.4 \pm 1.28$ & $7.8 \pm 1.82$ & $8.2 \pm 1.71$ & $10.6 \pm 1.46$ & $10.8 \pm 2.41$ \\
& Tr & 8 & $10.2 \pm 3.15$ & $11.6 \pm 3.15$ & $13.4 \pm 5.95$ & $13 \pm 4.48$ & $11 \pm 3.27$ \\
\hline \multirow{2}{*}{ Worker PI } & Control & 8 & $4.3 \pm 3.84$ & $6.3 \pm 4.37$ & $3.3 \pm 1.33$ & $8.3 \pm 2.40$ & $14 \pm 3.46$ \\
& $\operatorname{Tr}$ & 8 & $2 \pm 1.15$ & $4 \pm 1.52$ & $0 \pm 0$ & $9.7 \pm 3.75$ & $12 \pm 5.50$ \\
\hline
\end{tabular}

$\mathrm{n}$, number of colonies; PIR, percent infestation; Tr, treatment group; SEM Standard error of the mean

Table 3. Change in adult bee population (number of frames covered with bees) and brood area over time in the treatment and control group (Mean \pm SEM)

\begin{tabular}{l|cccccccc}
\hline Variable & Group & $\mathrm{n}$ & May 10 & May 30 & June 20 & July 10 & July 30 & Aug 20 \\
\hline \multirow{2}{*}{ ABP } & Tr & 8 & $5.00 \pm 0.00$ & $6.87 \pm 0.12$ & $11.75 \pm 0.67$ & $13.50 \pm 0.50$ & $8.75 \pm 0.16$ & $8.75 \pm 0.16$ \\
& Control & 8 & $5.00 \pm 0.00$ & $6.75 \pm 0.25$ & $12.12 \pm 0.74$ & $14.37 \pm 1.01$ & $9.12 \pm 0.22$ & $8.50 \pm 0.80$ \\
\hline \multirow{2}{*}{ BA } & Control & 8 & $5.00 \pm 0.00$ & $6.50 \pm 0.18$ & $8.75 \pm 0.31$ & $8.12 \pm 0.22$ & $8.75 \pm 0.16$ & $6.25 \pm 0.49$ \\
& Tr & 8 & $5.00 \pm 0.00$ & $6.25 \pm 0.26$ & $8.62 \pm 0.26$ & $8.50 \pm 0.18$ & $8.37 \pm 0.92$ & $6.25 \pm 0.99$ \\
\hline
\end{tabular}

$\mathrm{n}$, number of colonies; ABP, adult bee population; BA, brood area; Tr, treatment group; SEM, Standard error of the mean

Calculation of Varroa Mite Destruction Effect of Drone Comb Cells

The effect value of destruction of drone comb cells that were provided to the treatment colonies after trapping was calculated according to the formula below (Çetin, 2010).

Effect value $(\%)=((\mathrm{PAT} \times \mathrm{FPC}) /(\mathrm{PBT} \times \mathrm{IPC})) \times 100$

PAT :Percent infestation after treatment (treatment group)

FPC :Final percent infestation of control group

PBT :Percent infestation before the treatment (treatment group)

IPC :Initial percent infestation of control group)

\section{Determination of Colony Development}

Before the trial, the colonies were evened out with 5 frames (equal bees and capped brood). This was done to determine whether caging of the queen bee to the drone comb for 24 hours would make any regression in population development. For the above aim, bee and brood frame counts were recorded in both treatment and control group colonies during the study period.

\section{Statistical Analysis}

Varroa destructor percent infestation between groups was analysed by Mann-Whitney $\mathrm{U}$ Test. The change in $V$. destructor percent infestation between groups during the trial was analysed by One-Way ANOVA. V. destructor percent infestation within the groups was tested by the Wilcoxon Test. To compare colony development between groups, bee and brood frame quantities were tested by the Repeated Measures Test. Cross group V. destructor's comparison of drone and worker bee cell brood preference was analysed by Independent Sample T-test. SPSS program version 17 was used in all statistical analyses (SPSS, 2008), and all statements of significance were confirmed at $\mathrm{P}<0.05$ level. 


\section{Results}

\section{Comparison of Varroa Destructor Population of Pre and Post-trial}

The Varroa destructor mean abundance (percent infestation) obtained before and after the trial is shown in Table 1. In the treatment and control group, the Varroa destructor mean abundance was $1.87 \pm 0.31$ and $1.49 \pm 0.35$, respectively at the beginning of the trial (May 10, 2019). There was no statistical difference in the Varroa destructor mean abundance among trial groups before the study $(\mathrm{P}>0.05)$. Furthermore, in the treatment and control groups, the $V$. destructor mean abundance per colony was $12.14 \pm 0.75$ and $21.37 \pm 3.3$, respectively at the end of the trial (August 20, 2019). After the trial, the treatment group had approximately $43 \%$ lower $V$. destructor mean abundance (percent infestation) than the control group $(\mathrm{P}<0.05)$.

\section{Rate of Change of Varroa Destructor Infestation Rate Overtime During the Trial}

Varroa destructor infestation rate (mean abundance) over time is shown in Figure 1a,b. The results showed that the statistical difference in the Varroa destructor mean infestation rate in both the treatment and control group was significant on 20th June $(\mathrm{P}<0.01)$, 10th July $(\mathrm{P}<0.01)$, and 20th August $2019(\mathrm{P}<0.05)$. However, no significant difference was found on 10th May, 30th May, and 30th July 2019 ( $\mathrm{P}>0.05)$.

\section{Drone and Worker Bee Brood Preference by Varroa Destructor}

In the study, no statistical difference was found between the groups in terms of Varroa destructor infestation rate in drone and worker bee brood over time ( $\mathrm{P}>0.05)$. Infestation of drone and worker brood (pupae) by varroa is given in Table 2 . The preference for drone brood cells by the varroa was on average 1.6 times more than in the worker group colonies. On the other hand, the parasite's preference for worker bee brood was on average 1.3 times more in control group colonies than in the treatment group. In May, June, and July, the preference for drone bee brood by the parasite was higher than in August.

\section{Determination of Change of Adult Bee Population and Brood Area (Colony Development)}

The adult bee population data of the trial groups is shown in Table 3. The change in the adult bee population (number of frames covered with bees) throughout the study was statistically significant $(\mathrm{P}=0.000, \mathrm{P}<0.05)$. However, there was no statistical difference in the adult bee population between groups over time (time $\times$ group interaction) $(\mathrm{P}=0.635, \mathrm{P}>0.05)$. In the treatment group colonies, it was observed that caging the queen bees to the drone frame for 24 hours did not affect colony development. Statistical data on the brood area (number of frames covered with brood) over time in the treatment and control groups is shown in Table 2. Change in brood area over time between groups was found to be statistically significant $(\mathrm{P}=0.000, \mathrm{P}<0.05)$. The change in brood area over time between the treatment and control groups (time $\times$ group interaction) was not statistically significant $(\mathrm{P}=0.796, \mathrm{P}>0.05)$.

\section{Discussion}

In this study, the effect value of using drone bee honeycomb as a trap on $V$. destructor infestation rate was found to be approximately $43 \%$. This value has been confirmed as 44\% (Huang, 2001; Wilkinson and Smith, 2002; Charrierere et al., 2003; Wantuch and Tarpy, 2009; Al Toufailia et al., 2018; Wang et al., 2019), 91.14\% (Çetin, 2010), 71\% (Calderone, 2005), and 67-96\% (Calis et al., 1999). Furthermore, when this Varroa destructor biological control method is compared to the method of sprinkling icing sugar in some studies, the effect value (43\%) partially harmonizes with the $39.72 \%$ and $44.26 \%$ effect value of powdered sugar application to colonies in the morning and afternoon, respectively (Muz et al., 2014). With such a difference in effect value, it is thought that it may be more effective to combine both the drone bee brood trap and the powdered sugar sprinkling methods to obtain synergistic effects. In the current study, the change of Varroa destructor infestation rate over time is in line with Wilkinson and Smith (2002) who identified that using drone bee brood as a trap can delay $V$. destructor from reaching a harmful population for up to four months. Similarly, Wantuch and Tarpy (2009) stated that drone brood destruction was effective in controlling varroa until the end of summer. In addition, Traynor et al. (2020) concluded that the changes in the quantity of existing worker and drone brood over time influence the ratio of varroa mite in brood as opposed to adult bees. Similarly, we observed that there was a change in varroa mite percent infestation in both worker and drone brood cells over the course of the trial although no significant difference was identified between the groups (treatment and control).

The change in the adult bee population is expected because the study started at the beginning of May and continued until mid-August. For beekeeping, under normal circumstances, there is an increase in the adult bee population until the end of July when honey is harvested, and a decrease after harvesting. On the other hand, the change in brood area between groups being statistically significant, and in both groups being constant is also expected. This is because, in the Nigde province, where the study was carried out, brood increases continuously until the first week of August, and decreases afterward. The nonstatistical significance in the change between the treatment and control groups for the brood area may emphasize that caging the queen bee to the drone frame for 24 hours has no negative effect on the brood area. Similarly, Calderone (2005) found that caging of the queen bee to the drone frame has no negative impact on colony development. Our study identified no adverse effects of drone brood cell treatment on adult bee mortality, brood production, and colony population. This could be associated with a lack of inefficiencies caused by overdose, temperature, humidity, etc as observed in chemical and organic control applications (Gregorc and Sampson, 2019; Szczurek et al., 2019; Guichard et al., 2020). The use of drone bee brood cells as traps against varroa mite can be easily applied in colonies over time of high brood activity. In line with our study results, Charrière et al. (2003) reported that both colony development and honey production were not affected by the destruction of drone bee brood in over two years of the study. Calderone (2005) emphasized that 
destroying one drone brood comb per month in spring and summer does not affect bee health, population development, and honey production.

In terms of preference, Allen (1965) determined that the drone comb was preferred by $V$. destructor 4 times more than the worker comb, and Traynor et al. (2020) found that varroa mite shows an 8 -fold preference for drone bee brood compared to 1.6 times in our study. Moreover, Fuchs (1990) stated that varroa preferred drone bee honeycomb 8.3 times more by mid-summer when brood and feeding were plenty. Like in our study, a higher preference of varroa mite for the drone bee brood was in May, June, and July. This emphasizes the point that varroa mite infestation rate changes with periods of the year. Furthermore, the study by Al Toufailia et al. (2018) identified that varroa prefers drone bee brood 13 times more than the worker brood which is a very higher preference value compared with the above-specified researchers and the current study.

\section{Conclusions}

Using the drone brood cell trapping method can protect against Varroa destructor which is one of the problems in honeybee production. It is concluded that the rate of $V$. destructor percent infestation is less than $43 \%$ when drone brood cells are applied to the colonies. In practical beekeeping applications, this method alone is not enough to combat Varroa destructor but can be used as an alternative control method. In particular, it can be applied over time when the brood and honey production continue in colonies. The application of removal and destruction of drone brood cells has positive effects such as ensuring bee health, enhancing colony development, and ensuring quality bee products. Therefore, if the application is used in combination with chemical and organic methods, there can be a reduction in the use of chemicals for the control of varroa mite.

\section{References}

Al Toufailia H, Scandian L, Ratnieks FL. 2018. Towards integrated control of varroa: 3) mortality proportion from early spring trapping in drone brood. Journal of Apicultural Research, 57(3): 433-437. doi.org/10.1080/00218839.2018._1454292.

Allen MD. 1965. The effect of a plentiful supply of drone comb on colonies of honeybees. Journal of Apicultural Research, 4 (2): 109-119. doi.org/10.1080/00218839.1965.11100114.

Anderson DL, Trueman JW. 2000. Varroa jacobsoni (Acari: Varroidae) is more than one species. Experimental and applied acarology, 24(3): 165-189.

Berry JA, Hood WM, Pietravalle S, Delaplane KS. 2013. Fieldlevel sublethal effects of approved bee hive chemicals on honey bees (Apis mellifera L). PloS One, 8(10): e76536. doi.org/10.1371/journal.pone.0076536.

Calderone NW. 2005. Evaluation of drone brood removal for management of Varroa destructor (Acari: Varroidae) in colonies of Apis mellifera (Hymenoptera: Apidae) in the northeastern United States. Journal of Economic Entomology, 98(3): 645-650. doi.org/10.1603/0022-049398.3.645.

Calis JN, Boot WJ, Beetsma J, Van Den Eijnde JH, De Ruijter A, Van Der Steen JJ. 1999. Effective biotechnical control of Varroa: applying knowledge on brood cell invasion to trap honey bee parasites in drone brood. Journal of Apicultural Research, 38(1-2): 49-61. doi.org/10.1080/00218839.1999. 11100995 .
Charrière JD, Imdorf A, Bachofen B, Tschan A. 2003. The removal of capped drone brood: an effective means of reducing the infestation of varroa in honey bee colonies. Bee World, 84(3): 117-124. doi.org/10.1080/0005772X.2003. 11099587.

Çetin M. 2010. Bal Arısı (Apis mellifera L.,) Kolonilerinde Varroa destructor'un Kontrolünde Bitkisel, Kimyasal ve Biyoteknik Uygulama Yöntemlerinin karşılaştırılması. Yüksek Lisans Tezi. Çukurova Üniversitesi, Fen Bilimleri Enstitüsü, Adana, 2010. (In Turkish).

Fuchs S. 1990. Preference for drone brood cells by Varroa jacobsoni Oud in colonies of Apis mellifera carnica. Apidologie, 21(3): 193-199. doi.org/10.1051/apido:19900 304.

Goodwin RM, Taylor MA, McBrydie HM, Cox HM. 2005. Base levels of resistance to common control compounds by a New Zealand population of Varroa destructor. New Zealand Journal of Crop and Horticultural Science, 33(4): 347-352. doi.org/10.1080/01140671.2005.9514369.

Goulson D, Nicholls E, Botías C, Rotheray EL. 2015. Bee declines driven by combined stress from parasites, pesticides, and lack of flowers. Science, 347: 6229. doi.org/10.1126/ science. 1255957.

Gregorc A, Sampson B. 2019. Diagnosis of Varroa Mite (Varroa destructor) and Sustainable Control in Honey Bee (Apis mellifera) Colonies-A Review. Diversity, 11(12): 243. doi.org/10.3390/d11120243.

Guichard M, Dietemann V, Neuditschko M, Dainat B. 2020. Advances and perspectives in selecting resistance traits against the parasitic mite Varroa destructor in honey bees. Genetics Selection Evolution, 52(1): 1-22. doi.org/10.1186/ s12711020-00591-1.

Huang Z. 2001. Mite zapper-a new and effective method for Varroa mite control. American Bee Journal, 141(10): 730-732.

Ifantidis MD. 1983. Ontogenesis of the mite Varroa jacobsoni in worker and drone honeybee brood cells. Journal of Apicultural $\begin{array}{lll}\text { Research, 22(3): 200-206. doi.org/10.1080/002 } & 0\end{array}$ 18839.1983.11100588.

Klein AM, Vaissiere BE, Cane JH, Steffan-Dewenter I, Cunningham SA, Kremen C, Tscharntke T. 2007. Importance of pollinators in changing landscapes for world crops. Proceedings of the royal society B: Biological Sciences, 274 (1608): 303-13. doi.org/10.1098/rspb.2006.3721.

Liu Z, Chen C, Niu Q, Qi W, Yuan C, Su S, Liu S, Zhang Y, Zhang X, Ji T, Dai R. 2016. Survey results of honey bee (Apis mellifera) colony losses in China (2010-2013). Journal of Apicultural Research, 55 (1): 29-37. doi.org/10.1080/00218 839.2016.1193375.

Mancuso T, Croce L, Vercelli M. 2020. Total brood removal and other biotechniques for the sustainable control of Varroa mites in honey bee colonies: economic impact in beekeeping farm case studies in northwestern Italy. Sustainability, 12(6):2302. doi.org/10.3390/su12062302.

Martin SJ. 1994. Ontogenesis of the mite Varroa jacobsoni Oud. in worker brood of the honeybee Apis mellifera L. under natural conditions. Experimental and Applied Acarology, 18(2): 87100. doi.org/10.1007/BF00055033.

Muz MN, Aslan S, Girişgin AO. 2014. Balarılarında Varroa destructor Enfestasyonuna Karşı Pudra Şekeri Etkinliğinin Araştırılması. Uludağ Üniversitesi Veteriner Fakültesi Dergisi, 33(1-2): 21-26. (In Turkish).

Panziera D, van Langevelde F, Blacquière T. 2017. Varroa sensitive hygiene contributes to naturally selected varroa resistance in honey bees. Journal of Apicultural Research, 56(5): 635-642. doi.org/10.1080/00218839.2017.1351860.

Potts SG, Roberts SP, Dean R, Marris G, Brown MA, Jones R, Neumann P, Settele J. 2010 Declines of managed honey bees and beekeepers in Europe. Journal of Apicultural Research, 49(1): 15-22. doi.org/10.3896/IBRA.1.49.1.02.

Ramsey SD, Ochoa R, Bauchan G, Gulbronson C, Mowery JD, Cohen A, Lim D, Joklik J, Cicero JM, Ellis JD, Hawthorne D. 2019. Varroa destructor feeds primarily on honey bee fat body tissue and not hemolymph. Proceedings of the National Academy of Sciences, 116(5): 1792-1801. doi.org/10.1073/ pnas. 1818371116. 
Rehm SM, Ritter W. 1989. Sequence of the sexes in the offspring of Varroa jacobsoni and the resulting consequences for the calculation of the developmental period. Apidologie, 20(4): 339-343.

Released SI. 2008. SPSS statistics for windows, version 17.0. Chicago: SPSS Inc.

Rosenkranz P, Aumeier P, Ziegelmann B. 2010. Biology and control of Varroa destructor. Journal of Invertebrate Pathology, 103: S96-119. doi.org/10.1016/j.jip.2009.07.016.

Smart MD, Otto CR, Carlson BL, Roth CL. 2018. The influence of spatiotemporally decoupled land use on honey bee colony health and pollination service delivery. Environmental Research Letter, 13(8): 084016. doi.org/10.3390/insects8020 048.

Szczurek A, Maciejewska M, Bąk B, Wilde J, Siuda M. 2019. Semiconductor gas sensor as a detector of Varroa destructor infestation of honey bee colonies-Statistical evaluation. Computers and Electronics in Agriculture, 162: 405-11. doi.org/10.1016/j.compag.2019.04.033.
Traynor KS, Mondet F, de Miranda JR, Techer M, Kowallik V, Oddie MA, Chantawannakul P, McAfee A. 2020. Varroa destructor: A Complex Parasite, Crippling Honey Bees Worldwide. Trends in Parasitology, 36(7): 592-606. doi.org/ 10.1016/j.pt.2020.04.004.

Wang H, Zhang L, Jin S. 2019. A Biological Method for Trapping Varroa destructor and Collecting Male Wasp Pupae. International Journal of Applied Agricultural Sciences, 5(4): 94. doi.org/10.11648/j.ijaas.20190504.13.

Wantuch HA, Tarpy DR. 2009. Removal of drone brood from Apis mellifera (Hymenoptera: Apidae) colonies to control Varroa destructor (Acari: Varroidae) and retain adult drones. Journal of Economic Entomology, 102(6): 2033-2040. doi.org/10.1603/029.102.0603.

Wilkinson D, Smith GC, Hutton S, York Y. 2002. Modeling the Efficiency of Sampling and Trapping Varroa destructor in the Drone Brood of Honey bees (Apis mellifera). American Bee Journal, 142(3): 209-212. 